\title{
NARCOLEPSY AND DEPRESSION
}

\author{
CARLA ADDA*, BEATRIZLEFĖVRE*, RUBENS REIMÃO**
}

\begin{abstract}
Narcolepsy main symptoms include excessive daytime sleepiness and cataplexy. Its chronic course is accompanied by psychosocial impaiment added to the difficulties and side effects of stimulants and tricyclics long term use. Depressive complaints are occasionally reported. The aim of this paper was to evaluate objectively the possibility of depression in a sample of 12 narcoleptics (7F;5 M), with mean age of 53 years (12 years SD), using the Beck Depression Inventory (BDI) and the Hamilton Rating Scale for Depression (HAM-D). The results showed absence of depressive disorder in $75.0 \%$ of the cases according to BDI (or 58.3\% according to HAM-D). The remaining patients had mild depression (only one patient presented major depression). The findings showed no correlation between narcolepsy and major depression.
\end{abstract}

KEY WORDS: narcolepsy, depression, sleep, sleep disorder, Beck Depression Inventory, Hamilton Rating Scale for Depression.

\section{Narcolepsia e depressão}

RESUMO - Narcolepsia é um distúrbio do sono caracterizado por sonolência diurna excessiva e ataques de cataplexia. Sendo crônico, traz uma série de dificuldades psicossociais às quais se aliam aquelas geradas pelos efeitos colaterais dos estimulantes e tricíclicos utilizados. Queixas depressivas sāo encontradas ocasionalmente. Esta pesquisa buscou verificar objetivamente a ocorrência de depressão em narcolépticos. Foi avaliado um grupo de 12 pacientes narcolépticos (7F; 5M) com média de idade de 53 anos (DP 12) usando-se como instrumentos o Inventário de Beck para Depressāo (BDI) e a Escala Hamilton de Depressāo (HAM-D). Os resultados demonstraram ausência de distúrbio depressivo em $75.0 \%$ dos pacientes avaliados pelo BDI e em $58.3 \%$ pela HAM-D. Os demais escores evidenciaram depressão leve ou disforia; depressão maior foi encontrada em apenas um caso. Tais achados nāo sugerem correlaçāo entre narcolepsia e depressão.

PALAVRAS-CHAVE: narcolepsia, depressāo, sono, distúrbio do sono, Inventário de Beck para Depressão, Escala Hamilton de Depressão.

Narcolepsy clinical characteristics include excessive daytime sleepiness and cataplexy. These symptoms impair daytime functioning and may be detected by the Multiple Sleep Latency Test, which also shows the presence of sudden onset REM periods. Cataplexy, the loss of muscle tone, may be triggered by sudden emotions like anger, fear, or happiness. Some of these patients also experience slcep paralysis and hypnagogic hallucinations ${ }^{11}$.

The chronic treatment encompasses stimulant drugs for the excessive daytime sleepiness, and tricyclics antidepressants for the cataplectic attacks. These drugs are used when necessary, therefore there may be periods of improvement in which the drugs are withdrawn. As side effects of these medications, cholinergic symptoms, hipertension and impotence are found. Sexual dysfunction is also reported as consequence of cataplectic attacks during intercourse 6 . Stimulant drugs amphetamine and metilphenidate - are known for tolerance and dependence potential, therefore careful chronic management is necessary.

Neurology Clinic Division, Hospital das Clínicas, São Paulo University Medical School: *Psychologist, Neuropsychology Service; **Assistant physician. Aceite: 10-março-1997.

Psicóloga Carla Adda - DIP, Serviço de Neuropsicologia, Divisão de Clínica Neurológica - Hospital das Clínicas da USP - Caixa Postal 8091 - 05403-970 Sāo Paulo SP - Brasil. 
Psychosocial difficulties are perceived by the narcoleptic patients before and after diagnosis. School, work and driving impairment, as well as unemployment are frequently found ${ }^{5,6,13,14,16}$. The excessive daytime sleepiness is usually the most impairing symptom, compromising job and social performance, what may lead the patient to avoid monotonous sleepiness inducing situations. As cataplexy may be triggered by strong emotions, including fear or laugh, these patients often try to keep emotions under control. This may lead to a generalized lack of emotional expression or to excessive control of potential triggers of emotions, avoiding social relations, ${ }^{1,13}$.Hypnagogic hallucinations may be inadvertedly diagnosed as schizophrenia ${ }^{8.17}$, and a long time may pass until proper diagnosis as achieved.

Psychological aspects have been studied in narcolepsy. Some authors suggest that no specific psychopathology is associated to it, but depressive complaints are occasionally reported ${ }^{4,5,6,17,18}$. The aim of this paper was to evaluate a group of narcoleptics focusing specifically on the diagnosis and quantification of depressive disorder.

\section{METHODS}

We studied a group of 12 narcoleptics comprising 7 females (58.3\%) and 5 males (41.6\%), taken consecutively among the narcoleptics evaluated in an outpatient clinic. The mean age was 53 years $(\mathrm{SD}=12)$, varying from 20-65 years. Diagnosis was previously made on the basis of standard clinical evaluation, polysomnography and Multiple Sleep Latency Test ${ }^{15}$.

Four patients were non-medicated by the time of the evaluation, because two of them had recent diagnosis of narcolepsy ( $2 \mathrm{~F}$ ); and the remaining two (IF; 1M) had been absent from the outpatient clinic more than one year.

In order to diagnose and measure depressive disorder, the Beck Depression Inventory (BDI) ${ }^{2,3}$ and the Hamilton Rating Scale for Depression (HAM-D) ${ }^{10}$ were applied. Statistical analysis was not applied in our sample due to its small size.

The BDI (self-applicable) was developed to objectively evaluate and measure the behavioral manifestations of depression. It is standardized, consistent and economic, being useful for research, as well as adequate for screening in mental health'. Its validation makes it proper for quantitative diagnosis ${ }^{3}$.

The original BDI is composed of 21 categories of symptoms and attitudes, with four or five answers options with values from 0 to 3 . The categories are: mood, pessimism, failure, dissatisfaction, guilt, punishment, self-recrimination, suicidal thoughts, tendency to cry, irritability, aloofness in interpersonal relationships, indecision, self-image, productivity reduction, sleep disorder, fatigue, loss of apetite, weight loss, somatic worries, libido decrease? .

The cut-off grade is variable ${ }^{3}$, depending on the objectives of the study and sample sizes. Scores 14,17 and 21 have been considered in several studies as cut-off points above which major depression may be identified ${ }^{12}$. A broad recent study evaluating a sample of Brazilian population, used the following scoring: 0-15, normal score; 16-20, suggestive of disphoria; above 21 ,suggestive or major depression ${ }^{4}$. We utilized such scoring cut-off lines in the present research.

The HAM-D is originally composed of 17 items, which encompass depressive mood, guilt, suicide, insomnia, work and social activities interest, slowness, excitement, phychical anxiety, somatic anxiety, somatic symptoms (gastrointestinal), general somatic symptoms, sexual drive, hypocondria, weight loss, discernment. There are four other additional items that were not included in the scale as they do not measure intensity but category of depression ${ }^{10}$.

The evaluation of presence and intensity of the HAM-D items is based on the patient's conditions in the moment of the interview. Some items, as those refering to sleep disorder, require retrospective evaluation. In regard to the scoring system ${ }^{10}$, the score is zero if the symptom is not present. Score 1 , is attributed to the presence of symptom, of mild degree. Score 2, presence of symptoms, of moderate degree. If the symptom only occasionally influences the patients, the score is 3 . If the symptom occurs in an extreme degree and more constantly, the score is 4 . In regard to the cut-off score, we adopted the following criteria: $0-7$, absence of depression; $8-15$, mild depression; 16 or more, major depression?2. 
Table 1 - Depressive disurder scores in narcoleptics evaluated by the Beck Depression Inventory.

\begin{tabular}{lcc}
\hline & $\begin{array}{c}\text { Medicated } \\
(\%)\end{array}$ & $\begin{array}{c}\text { Non-Medicated } \\
(\%)\end{array}$ \\
\hline Normal score & 87.5 & 50.0 \\
Disphoria & & 50.0 \\
Major depression & 12.5 & \\
\hline
\end{tabular}

Table 2 -Depressive disorder scores in narcoleptics evaluated by the Hamilton Rating Scale for Depression.

\begin{tabular}{lcc}
\hline & $\begin{array}{c}\text { Medicated } \\
(\%)\end{array}$ & $\begin{array}{c}\text { Non-medicated } \\
(\%)\end{array}$ \\
\hline Normal score & 65.5 & 50.0 \\
Mild depression & 25.0 & 50.0 \\
Major depression & 12.5 & \\
\hline
\end{tabular}

The scores regarding sleep disorder (insomnia) were not considered in BDI as well as in HAM-D in our sample because narcolepsy long term clinical evolution is often accompanied by nocturnal sleep impairment.

\section{RESULTS}

The BDI showed normal scores in nine patients (75.0\%); disphoria in two patients (16.6\%); major depression score in one patient $(8.3 \%)$.

The HAM-D evidenced scores related to absence of depression in seven patients (58.3\%); four patients (33.3\%) showed mild depression scores; one patient $(8.3 \%$ ) showed major depression score. BDI and HAM-D had similar scores in all but two of the cases.

Despite the small sample size, the use of medications (stimulants and tricyclic antidepressives) did not seem to be the only factor in promoting normal scores in BDI and HAM-D. Tables 1 and 2 evidenced that the percentage of patients with normal scores tended to be higher in medicated patients. Major depression was not present in the unmedicated group.

Among patients with scores compatible with absence of depressive disorder,the most often found answers were those related to sadness (41.6\% BDI; 50.0\% HAM-D), irritability/anxiety (50.0\% BDI and HAM-D), libido decrease (33.3\% BDI and HAM-D), and social activities reduction (41.6\% HAM-D).

\section{DISCUSSION}

According to the DSM-IV', the main characteristic in major depression is the presence of one or more major depressive episodes, without history of maniac episode. The major depressive episode is characterized by depressive mood, loss of interest or pleasure in activities, weight changes, psychomotor disturbance or slowness, insomnia, fatigue, feelings of guilt or depreciation, excessive worries about health, recurring thoughts of death, and concentration decrease. Psychosocial stress may be a predisposing factor of these episodes, as are chronic physical disease and psychoactive substance dependence.

However, dysphoria (or mild depression in the HAM-D) share similar symptoms with major depression, and may be diferentiated by duration and severity. It is characterized by a mild chronic syndrome with at least two of the mentioned criteria for depression'. Psychosocial stress factors may predispose to dysphoria.

In the total narcoleptic sample evaluated, the predominant scores showed absence of depression, followed by mild depression/dysphoria. Major depression was detected in one case only. Scores discrepancy between BDI and HAM-D was observed in two cases and may be attributed to intrinsic characteristics of each scale; and the symptoms evaluated are distinct in each scale, chosen among the wide range of depressive symptoms.

The presence of normal scores tended to be higher in the medicated patients. The small sample size prevented, however, further comparison. Stimulant drugs and tricyclics may improve narcoleptic as well as depressive symptoms. However, previous psychopathological traits are often seen in 
other depressive patients despite appropriate drug therapy. The normal scores might also be related to personal factors that influence living with such chronic disease.

One may look closely at the answers given by patients without depression. Some items are the same reported by those with depression, however distinct in their frequency and intensity. These were answers regarding sadness, reduction in social activities, irritability and decrease in sexual interest. Sadness, irritability and reduction in social activities indicate difficulties in living with such a chronic disease, which may show up at any moment with excessive daytime sleepiness and cataplexy, symptoms poorly understood by the society and frequently interpreted as laziness or lack of interest.

In an effort to protect themselves from social judgement, these patients often restrict their social interaction. They tum more intensely to their families, making the familial support fundamental. The proper access of patients and families to information about the disease may also be instrumental, in order to reduce their mystic fantasies and provide a more realistic, adequate living with narcolepsy.

\section{REFERENCES}

1. American Psychiatric Association. Diagnostic and statistical manual of mental disorders. Ed 4. Washington D.C.: A.P.A. Publ., 1994:339-349.

2. Bech P, Kastrup M, Rafaelsen O. Mini-compedium of rating scales. Acta Psychiatr Scand 1986;73(Suppl 326):10-28.

3. Beck AT, Ward CH, Mendelson M, Mock J, Erbaugh J. An inventory for measuring depression. Arch Gen Psychiatry 1961:4:53-63.

4. Billiard M, Seignalet J, Eliaou JF. La narcolepsie. In: Billiard M (ed). Le sommeil normal et pathologique. Paris: Masson, 1994:261-274.

5. Broughton WA, Broughto RJ. Psychosocial impact of narcolepsy. Sleep 1994;17(Suppl 8):S45-S49.

6. Broughton R, Ghanem Q, Hishikawa Y, Sugita Y, Nevsimalova S, Roth B. Life effects of narcolepsy.Can J Neurol Sci 1983;10:100-104.

7. Cunha JA. Psicodiagnóstico-R. Porto Alegre; Artes Médicas 1993:135-137.

8. Douglas AB, Hays P, Pazderka F, Russel JM. Florid refractory schizophrenias that turn out to be treatable variants of HLAassociated narcolepsy. J Nerv Ment Dis 1991;179:12-17.

9. Gorenstein C, Andrade L. Validation of a portuguese version of the Beck Depression Inventory and State-Trait Anxiety Inventory in Brazilian subjects. Braz J Med Biol Res 1996;29:453-457.

10. Hamilton M. A rating scale for depression. J Neurol Neurosurg Psychiatry 1960;23:56-62.

11. Hublin C, Kaprio J, Partinen M, Koskenvuo M, Heikkila K, Koskimies S, Guilleminault C. The prevalence of narcolepsy: an epidemiological study of the Finnish twin cohort. Ann Neurol 1994;35:709-716.

12. Kennedy SH, Kaplan AS, Garfinkel PE, Rockert W, Toner B, Abbey SE. Depression and anorexia nervosa and bulimia nervosa. J Psychosomat Res 1994;38:773-782.

13. Proença C, Lefevre B, Reimão R. Narcolepsia: comprometimento psicosocial. Reun Neurofisiol Clin 1993;8:46-49.

14. Reimão R. Narcolepsia. In: Reimāo R (ed). Sono: aspectos atuais. Sāo Paulo: Atheneu, 1990:87-100.

15. Reimão R. Narcolepsia: avanços no diagnóstico. Reun Neurofisiol Clin 1993;8:40-45.

16. Reimāo R, Lemmi H. Narcolepsy in childhood and adolescence. Arq Neuropsiquiatr 1991;49:260-264.

17. Royant-Parola S. Narcolepsy and the psychiatric tableau. Ann Med Psychol 1992:150:286-290.

18. Stepanski EJ, Markley JJ, Zorick FJ, Roth T. Psychometric profiles of patient populations with excessive daytime sleepiness. Henry Ford Hosp Med J 1990;4:219-222. 